\title{
In situ measurement of meiobenthic grazing rates on sediment bacteria and edaphic diatoms*
}

\author{
Paul A. Montagna** \\ Belle W. Baruch Institute for Marine Biology and Coastal Research \\ and \\ Department of Biology, University of South Carolina, Columbia, South Carolina 29208, USA
}

\begin{abstract}
A radioactive tracer technique was used to measure meiofaunal grazing on bacteria and diatom communities in natural sediments. Radioactive ${ }^{14} \mathrm{C}$-glucose and ${ }^{14} \mathrm{C}$-bicarbonate were used to label heterotrophs (bacteria) and autotrophs (diatoms), respectively. The labeled compounds were added to undisturbed sediment cores and incubated for $4 \mathrm{~h}$ at in situ temperatures. After incubation, radioactivity was determined for the sediment (microbes) and the major meiofaunal taxa. To quantify meiofaunal grazing on microbes, a 3-compartment model was used where: available label is not limiting, microbial uptake is linear, and meiofaunal uptake is hyperbolic. The formula to calculate meiofaunal grazing rate $(\mathrm{k})$ is: $\mathrm{k}=2 \mathrm{f} / \mathrm{t}$, where $\mathrm{f}=$ fraction of meiofaunal radioactivity (DPM) relative to microbial radioactivity at time t. Although microbial activity was greater in summer than winter, there were no differences between meiofaunal grazing rates in winter and summer Total meiofaunal ingestion of microbes was dominated by polychaetes. Preliminary results suggest that, on the average, $3 \%$ of the bacteria and $1 \%$ of the diatom communities were removed per hour Thus turnover times of approximately $30 \mathrm{~h}$ for bacteria and $6.5 \mathrm{~d}$ for diatoms are apparently sufficient to maintain the microbial community in steady state under the meiofaunal grazing regime. This meiofaunal grazing pressure $\left(60 \mu \mathrm{g}\right.$ bacterial $\mathrm{C}$ and $27 \mu \mathrm{g}$ diatom $\mathrm{C}$ ingested $\left.10 \mathrm{~cm}^{-2} \mathrm{~h}^{-1}\right)$ probably represents a significant stimulatory effect on the microbial community.
\end{abstract}

\section{INTRODUCTION}

Marine meiobenthos have been thought to have a very close trophic coupling with microbial communities (Coull, 1973; Gerlach, 1978; Tietjen, 1980; Kuipers et al., 1981). Nematodes and harpacticoid copepods are the 2 dominant taxa in the meiobenthos (McIntyre, 1969), and sediment bacteria and benthic diatoms are the most common producers of microbial food in marine sediments (Zobell and Feltham, 1942; Montagna et al., 1983). Laboratory studies have demonstrated that nematodes will grow well on bacteria (Schiemer et al., 1980; Schiemer, 1982b) and diatoms (Tietjen and Lee, 1973; Alongi and Tietjen, 1980). Harpacticoid copepods also grow well in the laboratory on diets of bacteria (Rieper, 1978) and

- Contribution No. 537 from the Belle W. Baruch Institute for Marine Biology and Coastal Research

- Present address: Lawrence Livermore National Laboratory, University of California, P. O. Box 5507, L-453, Livermore, California 94550, USA diatoms (Sellner, 1976; Ustach, 1982). Although meiofauna are known to eat bacteria and diatoms, there are few reports on the impact of meiofaunal grazing on natural microbial assemblages. This may be largely due to the absence of, or difficulty in, applying techniques to measure in situ grazing by small sediment-dwelling animals.

During the past decade, techniques for using radioactive tracers in food chain studies have been greatly refined. Most of the significant contributions for this methodology have come from studies of planktonic systems. Conover and Francis (1973) recognized the necessity of fully accounting for the movement of label within and between organisms. They repudiated many earlier studies which ignored recycling of label through respiration and/or excretion. Label movement is common in studies which utilized 'pre-labeled food'. When pre-labeled food is employed, Lampert (1975) concluded that loss of radioactive carbon dioxide, by recycling, must be studied during a feeding experiment and not afterwards. The first in situ grazing studies utilized pre-labeled food, $5 \mathrm{~min}$ incubation 
periods, and assumed recycling was zero in such short time periods (Haney, 1971). Daro (1978) offered a technique where pre-labeling of prey was not necessary for an in situ study. Like Haney, Daro assumed zero recycling during a short $(1 \mathrm{~h})$ incubation, thus employing a 3-compartment model for label flow: water to phytoplankton to zooplankton.

Daro added high specific activity ${ }^{14} \mathrm{C}$-bicarbonate tracer at the beginning of an experiment and assumed linear label accumulation in phytoplankton and hyperbolic accumulation in zooplankton. The grazing rates calculated by the tracer technique were comparable to those measured using the Coulter Counter method (Daro, 1978). Roman and Rublee (1981) verified the key assumptions in Daro's model by demonstrating that phytoplankton uptake was linear over $2 h$, and hyperbolic in zooplankton over $4 \mathrm{~h}$. They also extended the technique to measure zooplankton grazing on bacterioplankton. Montagna (1983) demonstrated the need for live controls in food-chain experiments that employ tracer added during the grazing period. Thus, techniques for modeling and measuring the processes involved in the in situ transfer of microbial matter through food chains are becoming more clearly defined.

This study presents modifications of the tracer techniques used by Daro (1978) that allow measurement of in situ grazing rates in benthic systems. The purpose of this study is to measure the grazing activities of meiofaunal taxa on bacteria and diatoms in natural saltmarsh sediments. The importance of that grazing in benthic processes is assessed by measuring the standing stocks of the 'small benthic community', and comparing meiofaunal grazing rates to microbial activity and turnover times.

\section{MATERIALS AND METHODS}

The study area was located in a Spartina alterniflora Loisel saltmarsh in the North Inlet estuary near Georgetown, South Carolina, USA $\left(33^{\circ} 20.0^{\prime} \mathrm{N}\right.$, $79^{\circ} 10.0^{\prime} \mathrm{W}$ ). The study site was in the high marsh (short Spartina), sensu Bell $(1979,1982)$, near a tidal creek. The sediments were composed of soft mud; details of the environment and meiofaunal community composition are described in Bell (1979). The study site was chosen because there was a conspicuous absence of macrofauna, and there were no obvious biogenic structures. Additionally, the study site is adjacent to an area where benthic trophic relations are being studied by immunological techniques (Feller, pers. comm.). All my experiments were limited to the top centimeter of sediment; i.e. the aerobic zone where most of the meiofauna live (Coull and Bell, 1979). All experiments and measurements were run twice, once in summer (August, 1981) and once in winter (February, 1982), to contrast seasonal effects on the processes measured. The temperatures, $23^{\circ} \mathrm{C}$ in summer and $18^{\circ} \mathrm{C}$ in winter, were very similar.

\section{Measurements of grazing rates}

\section{Models}

The Daro (1978) model, as verified by Roman and Rublee (1981), was used to calculate grazing rates:

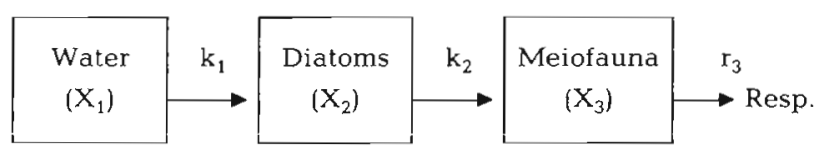

Where the flow of tracer is described by:

$$
\begin{aligned}
& \frac{\mathrm{d} \mathrm{X}_{1}}{\mathrm{dt}}=-\mathrm{k}_{1} \mathrm{X}_{1} \\
& \frac{\mathrm{d} \mathrm{X}_{2}}{\mathrm{dt}}=\mathrm{k}_{1} \mathrm{X}_{1}-\mathrm{k}_{2} \mathrm{X}_{2} \\
& \frac{\mathrm{d} \mathrm{X} \mathrm{X}_{3}}{\mathrm{dt}}=\mathrm{k}_{2} \mathrm{X}_{2}-\mathrm{r}_{3} \mathrm{X}_{3}
\end{aligned}
$$

In the experimental conditions given, label in water $\left(X_{1}\right)$ was not considered limiting (i.e. $X_{1}$ stayed approximately the same from time zero throughout the incubation time of the experiment), $X_{2}=X_{3}=0$ at time 0 , with short incubation times respiration $\approx 0$, and $\mathrm{k}_{1} \mathrm{X}_{1}$ $>>\mathrm{k}_{2} \mathrm{X}_{2}$ (i.e. tracer accumulation is linear in diatoms but hyperbolic in meiofauna). Given these conditions Daro (1978) has shown that the grazing rate $\left(k_{2}\right)$ can be calculated by the following formula:

$$
\mathrm{k}_{2}=\left(2 \mathrm{X}_{3}\right) /\left(\mathrm{X}_{2} \mathrm{t}\right)
$$

The rate constants $k_{1}$ and $k_{2}$ are transfer rates (in $h^{-1}$ ) and represent the fraction removed from the donor compartment per unit time.

The same basic model is used to measure meiofaunal grazing on bacteria. However, bacterial respiration of tracer can be important even in short-term experiments, depending on the organic compounds used. The model was modified for using glucose to label bacteria as follows:

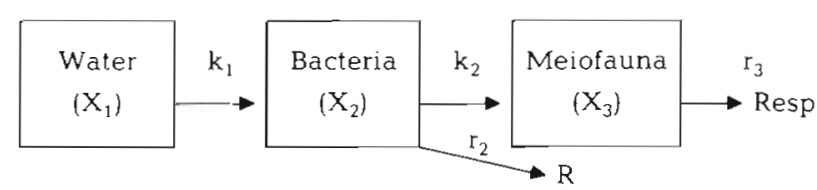


where the flow of tracer by bacteria is described by:

$$
\frac{d X_{2}}{d t}=k_{1} X_{1}-K_{2} X_{2}-r_{2} X_{2}
$$

where $R=D P M$ due to respired labeled carbon. Marine, bacterial respiration of glucose is a constant between 8 and $30 \%$ of total uptake (Hobbie and Crawford, 1969; Meyer-Reil, 1978; Azam and Hodson, 1981).

\section{Experiments}

D-[ $\left.{ }^{14} \mathrm{C}(\mathrm{U})\right]$-Glucose $\left(329 \mathrm{mCi} \mathrm{mmol}{ }^{-1}\right)$ and sodium ${ }^{14} \mathrm{C}$-bicarbonate $\left(7.0 \mathrm{mCi} \mathrm{mmol}^{-1}\right)$ were obtained from New England Nuclear, Boston, Massachusetts (USA) to label heterotrophs (bacteria) and autotrophs (algae) respectively in the grazing experiments. Tracers were diluted in sterile Instant Ocean (25 ppt) and filtered to remove particulate contamination.

At low tide, clear plastic core tubes $(4,44 \mathrm{~cm}$ i.d.; $15.5 \mathrm{~cm}^{2}$ ) were placed into the sediment to a depth of $1 \mathrm{~cm}$. The cores were removed from the sediment and the tops and bottoms of the tubes were stoppered. Five $\mathrm{ml}$ of labeled solution was pippetted onto the surface of the sediment. A total of $5 \mu \mathrm{Ci}$ bicarbonate and $1.5 \mu \mathrm{Ci}$ glucose were added to the autotrophic and heterotrophic cores, respectively, yielding final added concentrations of $97 \mathrm{ng}{ }^{14} \mathrm{C}$-glucose $\mathrm{cm}^{-2}$ and $2.8 \mu \mathrm{g}{ }^{14} \mathrm{C}$ bicarbonate $\mathrm{cm}^{-2}$. Cores with glucose added to label microheterotrophs (mainly bacteria) were incubated in the dark so that carbon dioxide respired by the bacteria would not be incorporated into photoautotrophs. Cores for measuring microautotrophic incorporation of labeled bicarbonate (mainly by diatoms) were incubated under $765 \mu$ Ein $\mathrm{m}^{-2} \mathrm{~s}^{-1}$ light as recommended by Zeeman (1983). The cores were incubated with label for $4 \mathrm{~h}$ at in situ temperatures $\left(23^{\circ} \mathrm{C}\right.$ in summer, $18^{\circ} \mathrm{C}$ in winter). Preliminary experiments demonstrated that shorter incubation times did not allow enough label to accumulate in meiofauna to ensure accurate label counting (see also Meyer-Reil and Faubel, 1980)

Two replicate cores were taken in summer and 3 were taken in winter for both heterotrophic and autotrophic grazing experiments. Variance of the tworeplicate samples was calculated by the method given in Snedecor and Cochran (1967: p. 40).

After the incubation period, the sediment was suspended in $100 \mathrm{ml}$ of Instant Ocean. A subsample of the sediment suspension was filtered to wash away unused label, and label incorporation by sediment microbes was measured from the sediment trapped on the filter. The remaining portion of the sample, containing meiofauna, was sieved and preserved in $2 \%$ formaldehyde solution. The meiofauna samples were sorted to major taxon in the order taken. When the samples could not be sorted in $1 \mathrm{~d}$, they were assigned a random sorting order to randomly distribute any effect due to tracer leakage should it occur during preservation. The meiofauna samples were sorted to major taxon within $21 \mathrm{~d}$, and $90 \%$ of the samples were sorted within $7 \mathrm{~d}$ after being collected. To solubilize cells and tissues, $1 \mathrm{ml}$ of Packard Soluene 100 was added to scintillation vials containing either subsamples of sediment microbes or the sorted meiofauna, and allowed to stand for 24 to $48 \mathrm{~h}$. Radioactivity was counted in a Packard Liquid Scintillation Counter, using Packard Instagel as a cocktail, for $60 \mathrm{~min}$ or until $10^{6}$ counts were reached. A quench curve was constructed by dilution series of estuarine sediment with ${ }^{14} \mathrm{C}$-toluene, and counting efficiency for each sample was determined from external standard channel ratios.

\section{Control experiments}

It was not possible to sort all the meiofaunal samples simultaneously and immediately after incubation with label; therefore, tests were performed to check for label loss during the brief preservation period. If label was leaking from the meiofauna, then the concentration of label in the preservation fluid would increase with time. Small aliquots $(20 \mu l)$ of the preservation fluid were taken each day (for $7 \mathrm{~d}$ ) from each of 5 nonsorted sample jars. Regression analysis was used to test whether the label concentration in the preservation fluid was increasing with time.

Linearity of label uptake by diatoms and bacteria was checked by a time series of incubations. Smaller cores $\left(1.1 \mathrm{~cm}^{2}\right.$ area) were used in this experiment, but the final label concentration was the same as in the grazing experiments. Bacterial uptake was checked by adding radioactive glucose and incubating in the dark. Corrections for abiotic uptake were made by subtracting values from parallel, formaldehyde-poisoned controls. Diatom uptake was checked by adding labeled bicarbonate, incubating in the light, and subtracting dark incubation values as controls

To account for uptake of organic ${ }^{14} \mathrm{C}$ by meiofauna kinetic control experiments were necessary (Montagna, 1983). Meiofauna uptake of glucose was measured by incubating cleaned fauna in sterile Instant Ocean (Montagna, 1984) and predicted glucose uptake was subtracted as a control value from the grazing animals. For the diatom grazing experiment, where inorganic ${ }^{14} \mathrm{C}$ is used, a dark incubation was used to obtain control values. These control values are greater than values that would have been obtained by poisoned controls (Montagna, 1983); thus, yield slightly lower grazing rates than if formalin alone had been used. 


\section{Measurement of standing stocks}

Biomass of bacteria, diatoms, and meiofauna were measured by collecting random core samples at the study site during the same time that cores were collected for the grazing experiments. Different core sites, replication numbers, and analyses were performed for each group.

For bacteria, 4 cores were taken and preserved with $5 \%$ glutaraldehyde solution in cacodylate buffer. Direct cell counts were obtained by acridine orange epifluorescence microscopy (Daley and Hobbie, 1975) using Nuclepore filters (Hobbie et al., 1977). The procedures were modified for use in marine sediments by diluting and homogenizing the samples (Montagna, 1982). Photomicrographs were taken during the counting process so that cell sizes could be measured later. Epifluorescence microscopy is preferred over scanning electron microscopy for measuring cell sizes because variable shrinkage occurs during sample preparation (Fuhrman, 1981). It was assumed that rods were cylindrical and cocci were spherical, and other rare cell shapes appeared to be elipsoid (Rodina, 1972). Length (L) and widths (W) were measured on 100 randomly chosen cells and cell volumes were calculated by the following formulas: cocci $=4 / 3 \pi(\mathrm{W} / 2)^{3}$; rods $=\pi \mathrm{L}$ $(\mathrm{W} / 2)^{2}$; ellipsoids $=4 / 3 \pi(\mathrm{L} / 2)(\mathrm{W} / 2)^{2}$. Cell biomass was determined by multiplying the cell biovolume by the conversion factor given by Ferguson and Rublee

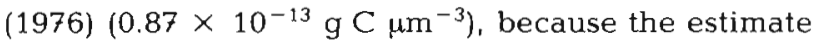
was based on marine bacteria from North Carolina.

Four cores were taken for diatom biomass determination. Each core $\left(1 \mathrm{~cm}^{3}\right.$ of mud) was ground with a mortar and pestle in $100 \%$ acetone for $2 \mathrm{~min}$. Chlorophyll a (Chl a) fluorescence in the extract was measured in a fluorometer (Holm Hansen et al., 1965) and Chl a content calculated by the following formula:

$$
\mathrm{mg} \mathrm{Chl} a \mathrm{~m}^{-2}=(0.00234)(2.10011)(\mathrm{B}-\mathrm{A})
$$$$
\text { (V/Area of core) }
$$

where $\mathrm{B}$ and $\mathrm{A}=$ fluorescence before and after acid was added to the sample $\mathrm{V}=$ volume of acetone into which the Chl a was extracted. Mean diatom biomass was estimated by multiplying mean Chl a concentration by a $\mathrm{C}$ : Chl a ratio for estuarine benthic diatoms given by de Jonge (1980) $[\overline{\mathrm{x}}=44.47, \mathrm{~s}==18.25, \mathrm{n}=$ 156].

The precision of microbial biomass estimates when obtained as a function of two estimates; i.e. $F(X, Y)=$ $\mathrm{x} * \mathrm{y}$, is:

$$
\operatorname{VAR}(X, Y)=\bar{y}^{2} s_{x}{ }^{2}+\bar{x}^{2} s_{y}{ }^{2}+2 \overline{x y} s_{x y}
$$

where $X$ and $Y$ are independent $s_{x y}=0$; therefore, the covariance term drops out (Kempthorne and Allmaras, 1965). For bacteria, $X$ is the estimate of cell abundance and $\mathrm{Y}$ is the estimate of cell biovolume. For diatoms, $\mathrm{X}$ is the estimate of $\mathrm{Chl}$ a concentration and $\mathrm{Y}$ is the estimate for the $\mathrm{C}$ : $\mathrm{Chl}$ a conversion ratio.

Meiofaunal biomass was determined from 4 random samples. The meiofauna were extracted and preserved in $5 \%$ glutaraldehyde in cacodylate buffer, later sorted to major taxa and frozen. The frozen samples were thawed, dried for $24 \mathrm{~h}$ at $55^{\circ} \mathrm{C}$ and the carbon and nitrogen concentrations determined in a Hewlett-Packard 185 CHN Analyser.

\section{Microbial activity}

Primary production was measured from the same cores used in the grazing study. Dark incubations were used to correct for non-photosynthetic uptake. Primary productivity was calculated by the method given in Strickland and Parsons (1972). A subsample of sediment from the diatom grazing experiment cores was used to obtain the uptake fraction of radioactive bicarbonate.

Heterotrophic activity was measured separately from the grazing experiment, by the tracer kinetic technique (Wright and Hobbie, 1966) with respiration correction (Hobbie and Crawford, 1969). Concentration ranges were suggested by Christian and Hall (1977) to be in the $\mathrm{ng} \mathrm{cm}^{-3}$ range. Sediment was collected, to a depth of $1 \mathrm{~cm}$, with $5 \mathrm{~cm}^{3}$ syringes which had their tops and bottoms removed (i.d. $=1.16 \mathrm{~cm}$, area $=$ $1.06 \mathrm{~cm}^{2}$ ). The bottom was corked with the plunger and serum bottle caps were used for the top. Two sets of cores were collected, one for sediment incorporation, a second set for respiration measurements. One $\mathrm{ml}$ of radioactive glucose was pipetted into each of two cores yielding $6,100,200$, and $300 \mathrm{ng} \mathrm{ml}^{-1}$ final concentrations, and the serum bottle caps were placed immediately onto the top of the cores. Cores were incubated in the dark at in situ temperatures. Heterotrophic uptake by the sediment was stopped at the end of the incubation period (4 h) by filtration (Griffiths et al., 1974). Parallel formalin-poisoned samples were used to correct for abiotic uptake of label. At the end of the incubation period the second set of cores was injected, through the serum cap, with $1 \mathrm{ml}$ of $1 \mathrm{~N}$ sulfuric acid to liberate respired carbon dioxide. After $1 \mathrm{~h}, 0.15 \mathrm{ml}$ of phenylethylamine was injected onto a paper wick to capture the released carbon dioxide. After $2 \mathrm{~h}$ the absorbed carbon dioxide was collected and counted. The assimilation and respiration measurements were analysed following the kinetic approach of Wright and Hobbie (1966). Since respiration and assimilation measurements were made independently, total glucose uptake was predicted by summing the assimilation and respiration regressions. 


\section{RESULTS}

The test for label leakage by preserved meiofauna indicated that meiofauna retained label. Analysis of Covariance (ANCOVA) demonstrated that label concentration in the 6 samples tested behaved in the same parallel fashion (ANCOVA test for homogeneity of slopes: $P=0.08$ ). The amount of radioactivity did not increase in any of the 6 samples (ANCOVA, $\mathrm{H}_{0}$ : slope of the covariable $=0, P=0.37$ ), indicating that label did not leak from preserved meiofauna for $7 \mathrm{~d}$. During the August experiment some microalgal samples were in preservative for as long as $21 \mathrm{~d}$. Almost all of the label loss, due to preservation, occurs during the first few hours, thereafter it hardly occurs at all (Persson, 1982). So, it is assumed that if leakage did occur, it occurred early.

Assumptions of the grazing model were verified by the results in Fig. 1 to 3. Uptake of labeled bicarbonate by sediment autotrophs was linear ( $r=0.94$, Fig. 1). Linearity of glucose uptake by heterotrophs was much weaker ( $r=0.59$, Fig. 2 ) because replicability of the measures appears to have been less precise than those for bicarbonate uptake. However, since a straight line fits the data and the intercept was not significantly different from zero $(P=0.12)$, the assumption of linearity is apparently confirmed. Meiofaunal incorporation of radioactive carbon confirms that meiofaunal uptake lags microbial uptake; i.e. meiofaunal uptake is hyperbolic (Fig. 3).

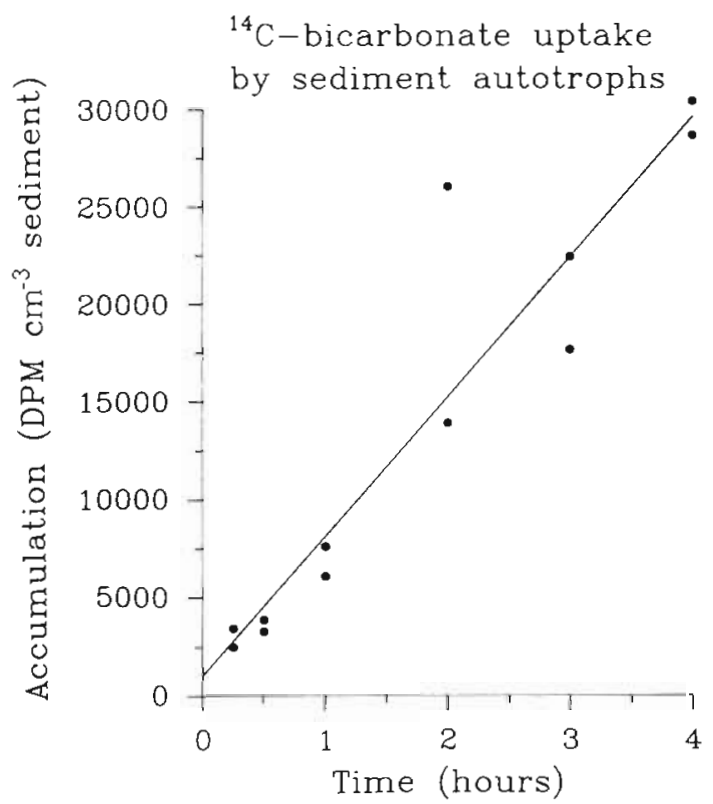

Fig. 1. Time series of autotrophic uptake of ${ }^{14} \mathrm{C}$-bicarbonate. Label accumulation in sediment microalgae was measured with respect to time. Each point is from an independent core sample. The line suggests the best fit by least square regression techniques

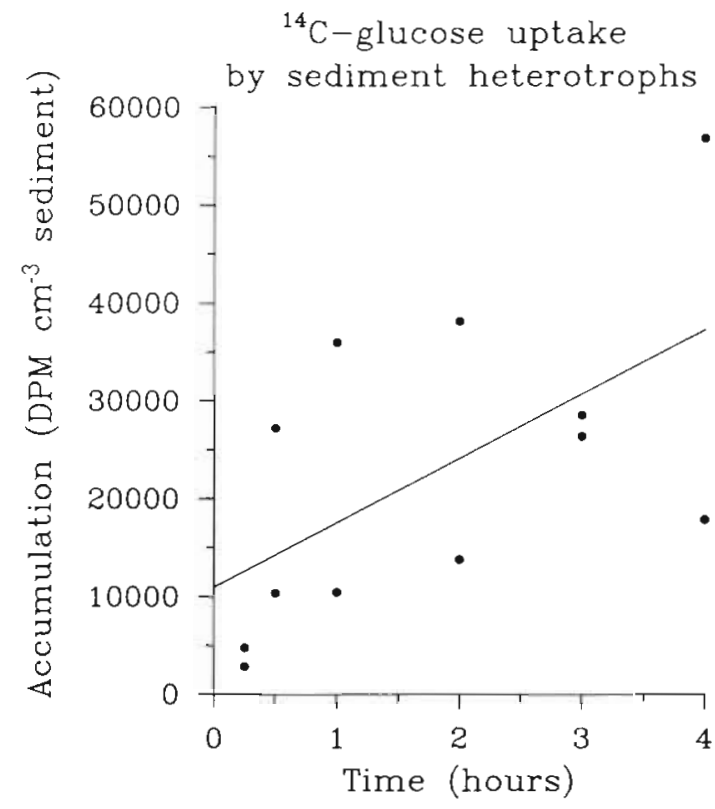

Fig. 2. Time series of heterotrophic uptake of ${ }^{14} \mathrm{C}$-glucose. Label accumulation in sediment bacteria was measured with respect to time. Each point is from an independent core sample. The line suggests that best fit by least square regression techniques

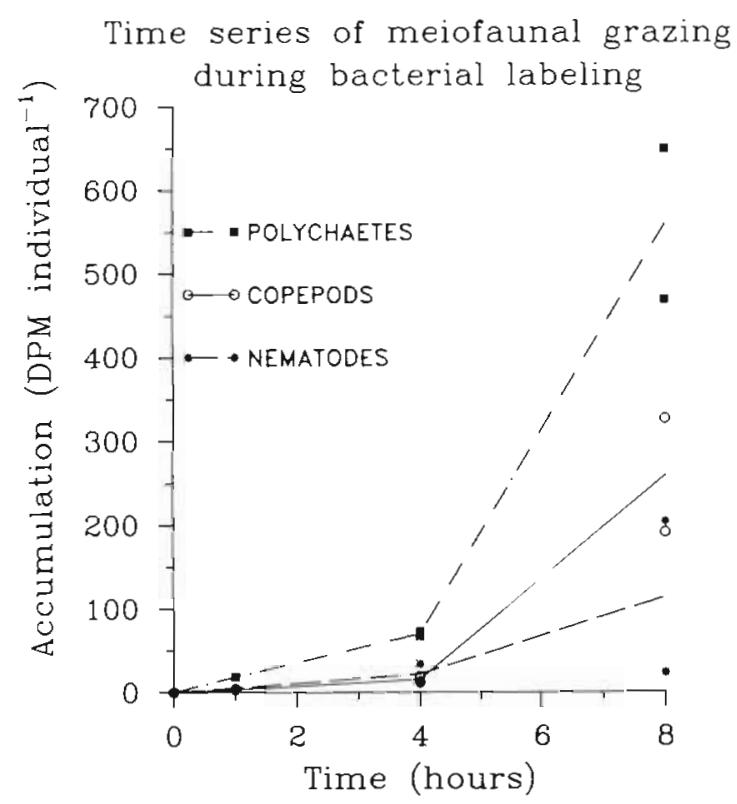

Fig. 3. Time series of meiofaunal uptake of ${ }^{14} \mathrm{C}$-glucose. Label accumulation of meiofauna during the labelling of sediment bacteria. The $0-, 1-$, and 4 -h points were measured on the same day. The $8 \mathrm{~h}$ points were measured on a different day and are shown to suggest a trend. The line was drawn by connecting the means at each time period

Standing stocks of the benthzic community were similar in both seasons (Table 1). Bacterial densities were higher in summer than winter $\left[9.04 \times 10^{10}\right.$ cells $10 \mathrm{~cm}^{-2}$ compared to $5.16 \times 10^{10}$ cells $10 \mathrm{~cm}^{-2}$ ( $t$-test: 
Table 1. Standing stocks of the benthic community. Mean biomass estimate for the 'small benthic community' at both sampling periods ( \pm variance). Note that $1 \mathrm{mg} \mathrm{C} 10 \mathrm{~cm}^{-2}=1 \mathrm{~g} \mathrm{C} \mathrm{m}^{-2}$

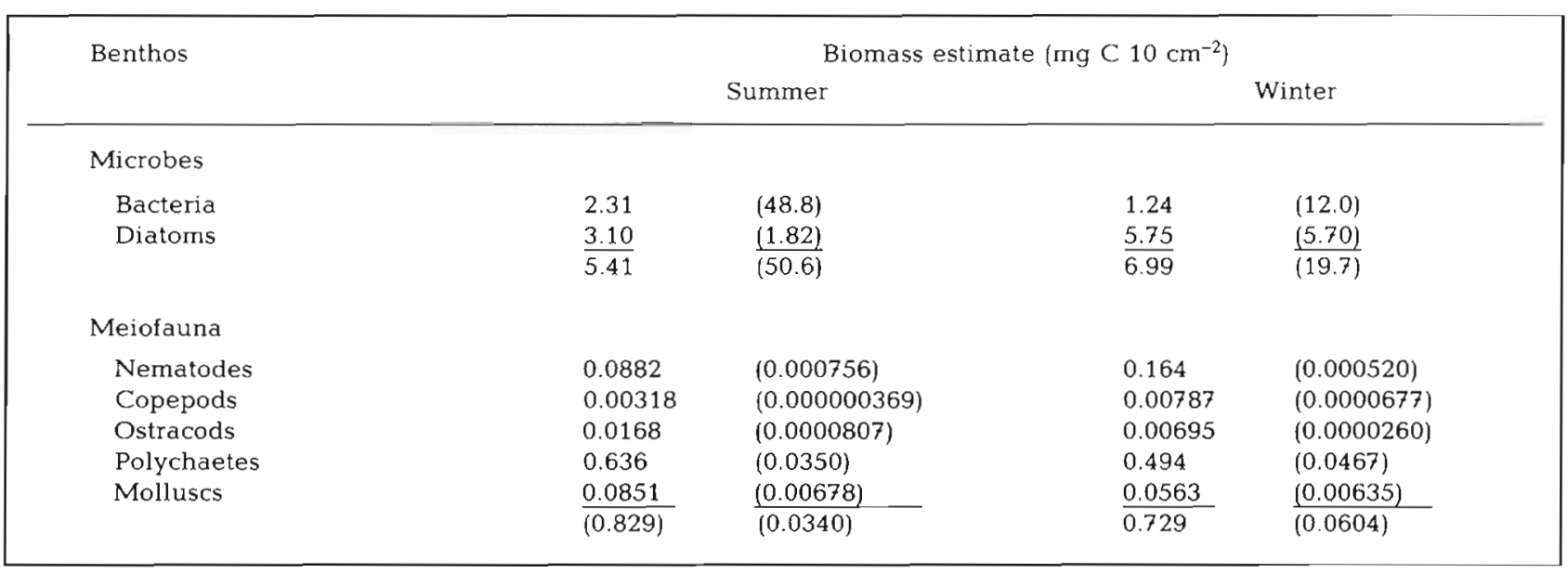

$P \leq 0.01)]$. Summer cell volumes $\left(0.293 \mu \mathrm{m}^{3}\right)$ were larger than in winter $\left(0.277 \mu \mathrm{m}^{3}\right)$ but not significantly ( $t$-test: $P \geq 0.05$ ). The net effect was that bacterial biomass was not different between the 2 seasons ( $t$ test: $P \geq 0.05$ ). The variance of the bacterial biomass estimate is very large (Table 1 ) since the estimate is a product of 3 numbers (cell size, cell abundance, a conversion factor) (Kempthorne and Allmaras, 1965). Chlorophyll content of winter sediments was approximately double that of summer, $129 \mu \mathrm{g} \mathrm{Chl} \mathrm{a} 10 \mathrm{~cm}^{-2}$ compared to $70 \mu \mathrm{g} \mathrm{Chl} \mathrm{a} 10 \mathrm{~cm}^{-2}$ ( $t$-test: $P \leq 0.0001$ ), and so was microalgal biomass (Table $1 ;$ t-test: $P<0.05)$. Meiofaunal biomass was the same ( $t$-test: $P=0.67)$ in winter and summer, $829 \mu \mathrm{g} \mathrm{C} 10 \mathrm{~cm}^{-2}$ compared to $729 \mu \mathrm{g} \mathrm{C} 10 \mathrm{~cm}^{-2}$. Polychaetes such as Manyunkia aestuarina are meiofaunal in size (Bell,
1982) and dominated the meiofaunal biomass (72.5\%); nematodes were second ( $16.2 \%)$, followed by juvenile bivalves $(9.1 \%)$, ostracods $(1.5 \%)$, and copepods

Table 2. Microbial activity during 2 seasons. Autotrophic activity given in terms of mean ( \pm variance) primary productivity $(n=3)$. Heterotrophic activity given in terms of glucose uptake kinetics for Fig. 4. Maximal uptake velocity $\left(v_{\max }\right)$ is the reciprocal of the slope of total uptake from Fig. 4

\begin{tabular}{|c|c|c|}
\hline \multirow[t]{2}{*}{ Season } & \multicolumn{2}{|c|}{ Microbial activity } \\
\hline & $\begin{array}{l}\text { Autotrophic } \\
\left(\mu \mathrm{g} \mathrm{C} 10 \mathrm{~cm}^{-2} \mathrm{~h}^{-1}\right)\end{array}$ & $\begin{array}{c}\text { Heterotrophic } \\
\left.\text { (ng glucose } \mathrm{cm}^{-2} \mathrm{~h}^{-1}\right)\end{array}$ \\
\hline Summer & $( \pm 9.0)$ & 89.8 \\
\hline Winter & $( \pm 1.2)$ & 15.9 \\
\hline
\end{tabular}

\section{Heterotrophic activity of sediment}

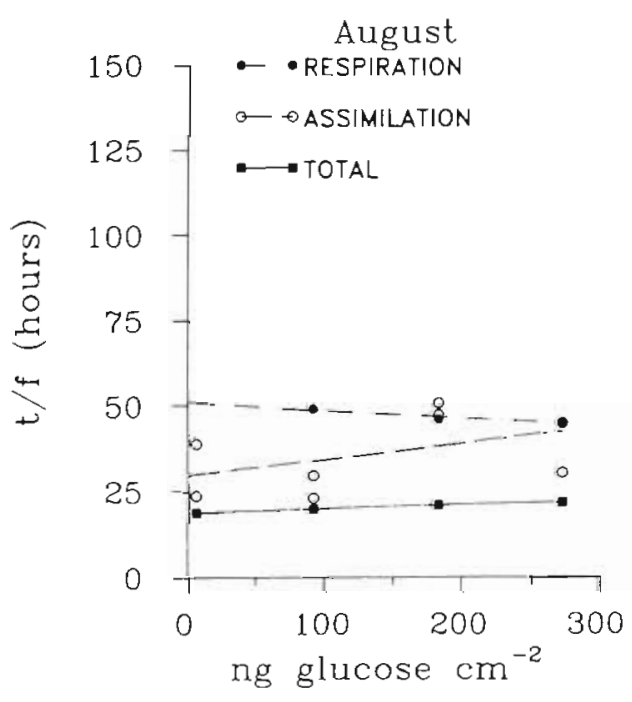

Fig. 4. Glucose uptake by sediment heterotrophs in 2 seasons. Turnover time of glucose is plotted against the substrate concentration. Respiration and assimilation was measured in independent cores containing approximately $1 \mathrm{~cm}^{3}$ of sediment. Total uptake was predicted by adding the regressions of assimilation and respiration together 
Table 3. Meiofaunal grazing on bacteria during 2 seasons. Mean grazing rate ( \pm variance) is given, 2 measurements were taken in summer and 3 in winter. Rate of bacterial ingestion was calculated by multiplying mean grazing rate (this table) by mean biomass value (Table 1); thus, the variance is a function of 4 products and is very large

\begin{tabular}{|c|c|c|c|c|}
\hline $\begin{array}{c}\text { Season } \\
\text { Animal group }\end{array}$ & \multicolumn{2}{|c|}{$\begin{array}{l}\text { Grazing rate } \\
\times 10^{-3}\left(\mathrm{~h}^{-1}\right)\end{array}$} & $\begin{array}{l}\text { Bacteria ingested } \\
\left(\mu \mathrm{g} \mathrm{C} 10 \mathrm{~cm}^{-2} \mathrm{~h}^{-1}\right)\end{array}$ & $\begin{array}{l}\text { Trophic turnover time } \\
\text { (h) }\end{array}$ \\
\hline Nematodes & 0.140 & $(0.0484)$ & 0.323 & 273 \\
\hline Copepods & 0.217 & $(0.00729)$ & 0.500 & 6 \\
\hline Ostracods & 0.0277 & $(0.0000250)$ & 0.0638 & 263 \\
\hline Polychaetes & 33.0 & $(799)$ & 76.0 & 8 \\
\hline Total & 33.3 & $(799)$ & 76.9 & 11 \\
\hline \multicolumn{5}{|l|}{ Winter } \\
\hline Nematodes & 0.342 & $(0.000772)$ & 0.425 & 386 \\
\hline Copepods & 0.274 & $(0.00359)$ & 0.341 & 23 \\
\hline Ostracods & 0.997 & $(0.848)$ & 1.24 & 6 \\
\hline Polychaetes & 31.0 & (198) & 38.5 & 13 \\
\hline Molluscs & 1.45 & $(3.25)$ & 1.76 & 32 \\
\hline Total & 34.0 & (204) & 42.3 & 17 \\
\hline
\end{tabular}

$(0.7 \%)$. The bivalve molluscs were juveniles that had probably recently settled out of the plankton and were temporary meiofauna. The variances of polychaetes and molluscs were very high compared to nematodes, ostracods, and copepods (Table 1) because the larger organisms were much more patchily distributed.

Although there was more Chl $a$ in the sediments during winter, the primary productivity of the diatoms in the winter was a third that of summer (Table 2). Heterotrophic tumover time of glucose was slower in winter than in summer (Fig. 4). The maximal uptake rate of glucose was 6 times faster in summer than winter (Table 2). Respiration, as a percent of total heterotrophic activity, was higher in summer (43\%) than in winter $(25 \%)$ and increased with increasing substrate concentration.

The results of the in situ meiofaunal grazing experiments are shown in Tables 3 and 4 . The meiofaunal grazing rate $\left(k_{2}\right)$, calculated from Equation (4), is the turnover rate $\left(\mathrm{h}^{-1}\right)$ of microbes due to removal by meiofauna (i.e. grazing). Microbes ingested were calculated by multiplying the microbial standing stocks ( $\mu \mathrm{g} \mathrm{C} 10 \mathrm{~cm}^{-2}$ ), from Table 1 , by the grazing rate $\left(\mathrm{h}^{-1}\right.$ ) in Tables 3 and 4 , thus representing microbial carbon flow to meiofauna. The biomass specific turnover time (h) was calculated by dividing the meiofaunal biomass

Table 4. Meiofaunal grazing on diatoms during 2 seasons. Mean grazing rate ( \pm variance) is given, 2 measurements were taken in summer and 3 in winter. Rate of microalga ingestion was calculated by multiplying mean (this table) by mean biomass value (Table 1); thus, the variance is a function of 4 products and is very large

\begin{tabular}{|c|c|c|c|c|}
\hline $\begin{array}{c}\text { Season } \\
\text { Animal group }\end{array}$ & \multicolumn{2}{|c|}{$\begin{array}{l}\text { Grazing rate } \\
\times 10^{-3}\left(\mathrm{~h}^{-1}\right)\end{array}$} & $\begin{array}{l}\text { Microalgae ingested } \\
\left(\mu \mathrm{g} \mathrm{C} 10 \mathrm{~cm}^{-2} \mathrm{~h}^{-1}\right)\end{array}$ & $\begin{array}{l}\text { Trophic turnover time } \\
\qquad(\mathrm{h})\end{array}$ \\
\hline Nematodes & 2.29 & $(0.0515)$ & 7.11 & 12 \\
\hline Copepods & 0.477 & $(0.000280)$ & 1.48 & 2 \\
\hline Ostracods & 0.870 & $(2.38)$ & 2.70 & 6 \\
\hline Polychaetes & 3.85 & $(0.169)$ & 11.9 & 53 \\
\hline Total & 7.49 & $(2.92)$ & 23.2 & 36 \\
\hline \multicolumn{5}{|l|}{ Winter } \\
\hline Nematodes & 0.619 & $(0.100)$ & 3.56 & 46 \\
\hline Copepods & 0.313 & $(0.0104)$ & 1.80 & 4 \\
\hline Ostracods & 0.769 & $(0.0966)$ & 4.42 & 2 \\
\hline Polychaetes & 1.91 & $(1.71)$ & 11.0 & 45 \\
\hline Molluscs & 1.85 & (3.82) & 10.6 & 5 \\
\hline Total & 5.42 & $(5.74)$ & 31.4 & 23 \\
\hline
\end{tabular}


present ( $\mu \mathrm{g} \mathrm{C} 10 \mathrm{~cm}^{-2}$ ), from Table 1 by the microbes ingested $\left(\mu \mathrm{g} \mathrm{C} 10 \mathrm{~cm}^{-2} \mathrm{~h}^{-1}\right.$ ) from Tables 3 and 4 . This is time required for the meiofauna to consume its body weight in microbes. Bacteria were the principal source of microbial food ingested by the meiofaunal community (Tables 3 and 4 ). This process was dominated by polychaetes grazing on bacteria. Nematodes, copepods, and ostracods were ingesting diatom $\mathrm{C}$ faster than bacterial $C$ (Tables 3 and 4). Although juvenile bivalves were present in both summer and winter biomass samples (Table 1), they were found only in the winter grazing experiments (Tables 3 and 4). The newly settled bivalves ingested the least amount of bacteria (Table 3), but they ingested a great proportion of the diatoms (Table 4).

\section{DISCŨSSION}

\section{Evaluation of methods}

The tracer technique used in this study was developed to study the process of in situ grazing in planktonic communities (Daro, 1978; Roman and Rublee, 1981). The technique, as modified in the Methods section, also works well in benthic systems. Fig. 1 to 3 verify the assumptions inherent in Equation 4. But, glucose was a poor choice of tracer, because uptake was so variable (Fig. 2) and may even be multi-phasic (Azam and Hodson, 1981). Thymidine-( ${ }^{3} \mathrm{H}$ ) is probably a better choice as a heterotrophic tracer (Roman and Rublee, 1981). Also, the use of dual labels would allow the measurement of grazing on bacteria and diatoms in the same sample.

Not all bacteria incorporate glucose. But, as long as meiofauna did not discriminate between glucose utilizers and non-users, the tracer technique should not underestimate grazing. However, selection of bacteria (and diatoms) species is known to occur among meiofauna (Lee et al., 1977; Rieper, 1978, 1982; Tietjen, 1980; Vanden Berghe and Bergmans, 1981). The technique assumes that grazers do not discriminate between microbes that take up label and those that do not. This should be the subject of future studies.

Food value can also effect ingestion rates (Cammen, 1980; Taghon, 1981), so differences in grazing rates on bacteria and diatoms could be due to differences in assimilability or food quality, Little is known about assimilation of microbial $\mathrm{C}$ by meiofauna. Microbes may survive, or even be enhanced by, passage through the guts of invertebrates (Porter, 1976; Epp and Lewis, 1981). There may also be differences in assimilation of bacterial and microalgal $C$ by meiofauna, and the 2 groups may represent food of differing quality. For example, bactivorous nematodes have higher assimila- tion efficiencies than herbivorous nematodes (Tietjen, 1980) and harpacticoids assimilate bacterial $C$ faster than diatom $C$ (Brown and Sibert, 1977). The technique used in the present study measures ingestion, not assimilation.

Some meiofaunal taxa may be grazers and other taxa deposit feeders. The experiments are designed for grazers, i.e. animals that select particles. This technique is most powerful for use with those taxa that select their food and assimilate a high and constant percentage of what they ingest. Perhaps, deposit-feeders (polychaetes) should be considered separately from grazers (nematodes, copepods, and ostracods).

Intra-meiofaunal predation, ciliates, and detritus have not been studied. The role of ciliates in benthic trophic-dynamics is well documented (Fenchel 1969; Fenchel and Jørgensen, 1977). But, ciliates could not be studied with the methodologies ì used and they could have had a great impact on bacterial populations. Meiofauna eat ciliates (Rieper and Flotow, 1981) and other meiofauna (Coull, 1973). Since label would have to travel from producer to prey to predator, incorporation by the highest level would take more time but could be large due to concentration by the food chain. The role of predation could be investigated using 4-compartment models and varying incubation times. Detritus may also be food for meiofauna. For polychaetes, seaweed detritus is an important food source, but associated microbes are more important in Spartina alterniflora derived detritus (Findlay and Tenore, 1982). Thus, the technique probably measures microbe ingestion by detritivores as well as grazers.

Several key variables (microbial biomass, microbial $\mathrm{C}$ ingested, turnover time) are not measured directly. Estimates as functions of other estimates lead to very high variances (Kempthorne and Allmaras, 1965), and a large degree of uncertainty. Whereas we must be cautious basing conclusions on the latter measures, the grazing rate $\left(k_{2}\right)$ is measured directly and we can be more confident about it.

\section{Comparisons with laboratory studies}

The results of this in situ field study do not agree well with some published laboratory studies. The average in situ grazing rate for nematodes on bacteria $\left(0.217 \times 10^{-3} \mathrm{~h}^{-1}\right.$; Table 3$)$ was almost an order of magnitude higher than that reported in a lab study $\left(0.032 \times 10^{-3} \mathrm{~h}^{-1}\right)$ (Duncan et al., 1974). The laboratory study utilized prelabeled bacteria in a sloppy agar medium. The average nematode in situ grazing rate on diatoms $\left(1.44 \times 10^{-3} \mathrm{~h}^{-1}\right.$; Table 4) was also lower, than that reported by Admiraal et al. (1983), in a laboratory study which used prelabeled diatoms on 
Table 5. Meiofaunal preference. Selection measured as diatom : bacterial uptake ratios. Calculated by using average of winter and summer mean grazing values from Tables 3 and 4 indices $>1$ indicate diatom selection, indices $<1$ bacterial selection

\begin{tabular}{|lcc|}
\hline $\begin{array}{c}\text { Animal } \\
\text { groups }\end{array}$ & $\begin{array}{c}\text { Grazing rate } \\
(\mathrm{D} / \mathrm{B})\end{array}$ & $\begin{array}{c}\text { Microbes ingested } \\
(\mathrm{D} / \mathrm{B})\end{array}$ \\
\hline Nematodes & 6.1 & 14 \\
Copepods & 1.6 & 3.9 \\
Ostracods & 1.6 & 5.5 \\
Polychaetes & 0.090 & 0.20 \\
Molluscs & 1.3 & 6.0 \\
& & \\
D $=$ diatoms, B $=$ bacteria & \\
\hline
\end{tabular}

agar plates $\left(3.6 \times 10^{-3} \mathrm{~h}^{-1}\right)$. Copepods in the present study ingested diatom $C 1.6$ times faster than bacterial C (Table 5), whereas Brown and Sibert (1977) reported that three harpacticoid species selected bacterial $C$ over diatom $C$ (9.5 times). In their experiments the amount of diatom $\mathrm{C}$ was roughly equal to the amount of bacterial $\mathrm{C}$. In contrast, in situ algal $\mathrm{C}$ in the present study was 2.5 times greater than bacterial C. It is difficult to compare differences found between studies because members of the same harpacticoid species select different species of microbial food (Vanden Berghe and Bergmans, 1981). Also, laboratory strains of bacteria are much larger in size than those naturally occurring (Wilson and Stevenson, 1980).

Tietjen (1980) reviewed laboratory studies on microbial ingestion and found that the consumption of bacteria and algae clustered in the range between 0.1 to $10 \mu \mathrm{g}$ dry weight animal ${ }^{-1} \mathrm{~d}^{-1}$. Assuming carbon is $40 \%$ of dry weight, this range would be 0.04 to $4 \mu \mathrm{g} \mathrm{C}$ animal ${ }^{-1} \mathrm{~d}^{-1}$. The data from Tables 3 and 4 can be converted into these units. In summer, the meiofaunal taxa (copepods, nematodes, ostracods) ingested $0.042 \mu \mathrm{g}$ bacterial $\mathrm{C}$ animal ${ }^{-1} \mathrm{~d}^{-1}$, and $0.53 \mu \mathrm{g}$ algal $\mathrm{C}$ animal ${ }^{-1} \mathrm{~d}^{-1}$ In winter, these same taxa ingested $0.53 \mu \mathrm{g}$ of bacterial and $0.29 \mu \mathrm{g}$ of algal $\mathrm{C}$ animal ${ }^{-1} \mathrm{~d}^{-1}$. It appears that in situ microbial ingestion rates are in the low range of those measured in laboratory studies. However, I must caution the reader that the bounds of error around my estimates of ingested microbial biomass are very large (Tables 3 and 4), and temperature plays an important but undetermined role.

Although most meiofaunal groups exhibit slightly lower grazing rates and microbial ingestion in winter, compared to summer, the differences are not significant $(P \geq 0.05$ ) (Tables 3 and 4 ). However, there were small differences in temperature between summer $\left(23^{\circ} \mathrm{C}\right)$ and winter $\left(18^{\circ} \mathrm{C}\right)$. Also the microbial biomass did not change between the two seasons (Table 1 ).
Nematode respiration is known to increase with increasing bacterial food (Klekowski et al., 1979; Schiemer, 1982a), and bacterial consumption by harpacticoids increases with increasing food density (Rieper, 1978). Perhaps, the similar ingestion rates of winter and summer may be explained by the lack of changes in food density and the small temperature differences $\left(5^{\circ} \mathrm{C}\right)$.

\section{Trophic-dynamics and meiofaunal-microbial interactions}

The intertidal community of the high-marsh studied had a biomass pattern that conformed to the classic food-chain pyramids described by Elton (1927). Microbes (bacteria and diatoms) outweighed meiofauna by a factor of 8 (Table 1). The meiofaunal biomass found $\left(\overline{\mathbf{x}}=0.78 \mathrm{~g} \mathrm{~m}^{-2}\right)$ was within the range reviewed by Fenchel (1978). But it is probably low (perhaps as much as $38 \%$ ) because of losses of dry weight and nitrogen and carbon content due to preservation (Williams and Robins, 1982). The mean bacterial biomass $\left(1.78 \mathrm{~g} \mathrm{C} \mathrm{m}^{-2}\right)$ was similar to that found by Rublee (1982) in similar sediments from a North Carolina Spartina saltmarsh (1.47 $\mathrm{g} \mathrm{C} \mathrm{m}^{-2}$ ). Gerlach (1978) has suggested an average bacterial : meiofaunal biomass ratio of 5 ; but, other values range from 0.1 in mud flats from England (Warwick et al., 1979) to 13 in mud flats of Nova Scotia (Schwinghammer, 1981).

The patterns of microbial activity in the South Carolina saltmarsh are very similar to those reported in other environments. Heterotrophic activity in sediments was related to temperature in a positive fashion in this study as well as in the Baltic (Meyer-Reil, 1978). However, bacterial respiration accounted for 5.3 to $10.4 \%$ of the total uptake in the Baltic compared to an average of $34 \%$ in this study. The maximal uptake velocity (converted to $\mu \mathrm{g}$ glucose $\mathrm{g}^{-1}$ dry weight sediment $\mathrm{h}^{-1}$ ) was 0.172 for August and 0.0307 for February; which is in the range reported for intertidal flats in New Zealand, 0.08-5.10 $\mathrm{g} \mathrm{g}^{-1} \mathrm{~h}^{-1}$ (Gillespie and MacKenzie, 1981), and the Baltic Sea, 0.04 to $0.44 \mu \mathrm{g} \mathrm{g}^{-1} \mathrm{~h}^{-1}$ (Meyer-Reil et al., 1978). Edaphic microalgal productivity was identical to that reported in similar saltmarsh sediments from Georgia, USA, i.e. summer productivity ( $\mathrm{mg} \mathrm{C} \mathrm{m} \mathrm{m}^{-2} \mathrm{~h}^{-1}$ ) of 14.9 to 15.3 and in winter 5.0 to 7.3 (Darley et al., 1981). The general pattern in the present study was that microbial activity decreased in winter, while standing stocks remained the same.

The high marsh meiofaunal community is removing approximately $3 \%$ of the heterotrophic (bacterial) (Table 3 ) and $1 \%$ of the autotrophic (diatoms) standing stock per houx (Table 4). Although my data are very 
limited (i.e. 2 points), there is no evidence that grazing activity varies throughout the year. Polychaetes overwhelmingly dominated ingestion of bacterial C $(95 \%)$ and, to a lesser extent, ingestion of diatom C (35\%).

Food selection or preference can be calculated in 2 ways: as ratio of heterotrophic (bacterial) to autotrophic (diatom) grazing rates or as ratio of bacterial to diatom $\mathrm{C}$ ingested (Table 5). Whereas polychaetes grazed on bacteria faster than on diatoms (11:1), the traditional meiofaunal taxa graze at greater rates on diatoms (3:1 on average) (Table 5). Although there was 2.5 times more diatom carbon in sediment than bacterial carbon (Table 1), twice as much bacterial $\mathrm{C}$ was ingested than diatom $C$ by the meiofaunal community (Tables 3 and 4). It would appear that bacteria were being selected over diatoms as the preferred food source. But, this process is dominated by polychaetes eating bacteria. If only the traditional meiofaunal taxa (nematodes, copepods, ostracods) are considered then diatoms are selected 8 times greater than bacteria, suggesting these taxa are selecting diatoms (Table 5). Some nematode taxa are known to prefer diatoms as food (Tietjen and Lee, 1973).

If meiofaunal grazing rates were greater than microbial turnover times, then meiofauna would graze down the microbes and could become food limited. The observed grazing rates (Tables 3 and 4) suggest that bacteria would require turnover times of $30 \mathrm{~h}$ and diatoms $6.5 \mathrm{~d}$ to replace the population lost due to meiofaunal grazing. Admiraal et al. (1982) suggested that diatoms have turnover times of $3.3 \mathrm{~d}$ in (European) estuarine mudflats. Bacterial generation times in (southeastern North American) subtidal sediments range from 9.3 to $18.7 \mathrm{~h}$ (Newell and Fallon, 1982), and in (Australian) seagrass sediments from 5.5 h to $7.5 \mathrm{~d}$ (Moriarty and Pollard, 1981). So, a comparison of microbial turnover times and meiofaunal grazing rates suggests that meiofaunal grazing is in equilibrium with microbial production. The implication, based on ingestion rate data, is that food is not limiting to meiofauna at these densities. However, a comparison of microalgal production (Table 2) and microalgal consumption (Table 4) yields opposite results. Assuming that photosynthesis continues at the measured rate for $12 \mathrm{~h}$ (probably an overestimate), then primary production (in $\mu \mathrm{g} \mathrm{C} 10 \mathrm{~cm}^{-2} \mathrm{~d}^{-1}$ ) is 222 in summer and 65.5 in winter (Table 2). Assuming grazing is constant for $24 \mathrm{~h}$ (an assumption of unknown validity), then meiofauna consume 557 ( $\mu \mathrm{g} \mathrm{C} 10 \mathrm{~cm}^{-2} \mathrm{~d}^{-1}$ ) in summer, and $754 \mathrm{in}$ winter (Table 4). These estimates suggest 2 possibilities. Either meiofauna consumption can quickly outpace their food supply, or many of the diatoms ingested are passing through the guts in a viable state. Viable algae are known to pass through the guts of planktonic copepods (Porter, 1976). Epp and Lewis
(1981) have hypothesized a coevolutionary mechanism whereby animals allow ciatoms to pass through the gut but gain energy from gelatinous sheaths and photosynthates, growth factors such as vitamins, and an internal oxygen pump (which also removes $\mathrm{CO}_{2}$ ). This explanation seems more likely than food limitation.

In an earlier correlation study, fluctuations of meiofauna corresponded with fluctuations of diatoms. However, meiofauna abundances did not follow fluctuations in microbe abundances as would be predicted if microbial food was limiting (Montagna et al., 1983). The hypothesis of food limitation has also been rejected for the benthic community of the lower Chesapeake Bay (Dauer et al., 1982). Admiraal et al. (1983) also suggested that herbivores only convert $10 \%$ of the primary production and do not have a great impact on microphytobenthos in the Eems-Dollard estuary.

It has been suggested that meiofauna play an important role in recycling nutrients (McIntyre, 1969; Coull and Bell, 1979). Although the mechanism is not known, it is apparent that grazing has a stimulatory effect on bacteria (Fenchel and Jørgensen, 1977). Tenore et al. (1977) did find increased oxidation and turnover rates of aged eelgrass in the presence of meiofauna. The present study suggests that meiofauna can eat their body weight equivalent in microbes each day (Tables 3 and 4). This grazing pressure represents a significant stimulatory effect to the microbial community. Perhaps new concepts of microbial-invertebrate interactions will arise, where synergistic and/or mutualistic relations are seen, rather than predatory or competitive relations.

Acknowledgements. This paper was extracted from a dissertation submitted as partial fulfillment for the $\mathrm{Ph}$. D at the University of South Carolina, USA. Financial support was provided by the Belle W. Baruch Institute for Marine Biology and Coastal Research, the Department of Biology, Univ. of South Carolina, and the Biological Oceanography Program of the National Science Foundation (grant OCE-8007968: B. C. Coull, principal investigator). I am grateful to J. Morris for instructing me on the use of a CHN analyser, and S. Zeeman for advice on radioisotope techniques. I thank B. C. Coull, R. J. Feller, H. N. McKeller, M. A. Palmer, D. L. Wethey, and D. C. Yoch for their helpful comments during the preparation of this paper.

\section{LITERATURE CITED}

AdrniraaI, W., Peletier, H., Zomer, H. (1982). Observations and experiments on the population dynamics of epipelic diatoms from an estuarine mudflat. Estuar coast. Shelf Sci. 14: $471-487$

Admiraal, W., Bouwman, L. A., Hoekstra, L., Romeyn, K. (1983). Qualitative and quantitative interactions between microphytobenthos and herbivorous meiofauna on a brackish intertidal mudflat. Int. Revue ges. Hydrobiol. 68: $175-191$ 
Alongi, D. M., Tietjen, J. H. (1980). Population growth and trophic interactions among free-living marine nematodes. In: Tenore, K. R., Coull, B. C. (ed.) Marine benthic dynamics. University of South Carolina Press, Columbia, p. 151-166

Azam, F., Hodson, R. E. (1981). Multiphasic kinetics for Dglucose uptake by assemblages of natural marine bacteria. Mar. Ecol. Prog. Ser. 6: 213-222

Bell, S. S. (1979). Short- and long-term variation in a high marsh meiofauna community. Estuar. coast. Shelf Sci. 9: $331-350$

Bell, S. S. (1982). On the population biology and meiofaunal characteristics of Manayunkia aestuarina (Polychaeta: Sabellidae : Fabricinae) from a South Carolina salt marsh. Estuar. coast. Shelf Sci. 14:215-221

Brown, T. J., Sibert, J. R. (1977). The food of some benthic harpacticoid copepods. J. Fish. Res. Bd Can. 34: 1028-1031

Cammen, L. M. (1980). Ingestion rate: an empirical model for aquatic deposit feeders and detritivores. Oecologia 44: 303-310

Christian, R. R., Hall, J. R. (1977). Experimental trends in sediment heterotrophy: radioisotope techniques and analysis. In: Coull, B. C. (ed.) Ecology of marine benthos. University of South Carolina Press, Columbia, p. 67-88

Conover, R. J., Francis, V (1973). The use of radioactive isotopes to measure the transfer of materials in aquatic food chains. Mar. Biol. 18: 272-283

Coull, B. C. (1973). Estuarine meiofauna: a review: trophic relationships and microbial interactions. In: Stevenson, L. H., Colwell, R. R. (ed.) Estuarine microbial ecology. University of South Carolina Press, Columbia, p. 499-511

Coull, B. C., Bell, S. S. (1979). Perspectives of marine meiofaunal ecology. In: Livingstone, R. J. (ed.) Ecological processes in coastal and marine systems. Plenum Publishing Corp, New York, p. 189-216

Daley, R. J., Hobbie, J. E. (1975). Direct counts of aquatic bacteria by a modified acridine orange epifluorescence technique. Limnol. Oceanogr. 20: 875-882

Darley, W. M., Montague, C. L., Plumeley, F. G., Sage, W. W., Psalidas, A. T. (1981). Factors limiting edaphic algal biomass and productivity in a Georgia saltmarsh. J. Phycol. $17 ; 122-128$

Daro, M. H. (1978). A simplified ${ }^{14} \mathrm{C}$ method for grazing measurements on natural planktonic populations. Helgoländer wiss. Meeresunters. 13: 241-248

Dauer, D. M., Ewing, R. M., Tourtellotte, G. H., Harlan, W. T. Sourbeer, J. W., Barker, Jr., H. R. (1982). Predation, resource limitation and the structure of benthic infaunal communities of the lower Chesapeake Bay. Int. Revue ges. Hydrobiol. 67: 477-489

de Jonge, V. N. (1980). Fluctuations in the organic carbon to chlorophyll a ratios for estuarine benthic diatom populations. Mar. Ecol. Prog. Ser. 2: 345-353

Duncan, A., Schiemer, F., Klekowski, R. Z. (1974). A preliminary study of feeding rates on bacterial food by adult females of the benthic nematode, Plectus palustris De Man 1880. Pol. Arch. Hydrobiol. 21: 249-258

Elton, C. A. (1927). Animal ecology. Macmillan, New York

Epp, R. W., Lewis, Jr., W. M. (1981). Photosynthesis in copepods. Science, N. Y. 214: 1349-1350

Fenchel, T. M. (1978). The ecology of micro- and meiobenthos. Ann. Rev. Ecol. Syst. 9: 99-121

Fenchel, T. M. (1969). The ecology of marine microbenthos IV. Structure and function of the benthic ecosystem, its chemical and physical factors and the microfauna communities with special reference to the ciliated protozoa. Ophelia 6: 1-182
Fenchel, T. M., Jørgensen, B. B. (1979). Detritus food chains of aquatic ecosystems: the role of bacteria. In: Alexander, $M$. (ed.) Advances in microbial ecology. Plenum Press, New York, p. 1-58

Ferguson, R. L., Rublee, P. (1976). Contribution of bacteria to standing crop of coastal plankton. Limnol. Oceanogr. 21 $141-145$

Findlay, S. L., Tenore, K. (1982). Nitrogen source for a detritivore: detritus substrate versus associated microbes. Science, N. Y. 218: 371-373

Fuhrman, J. A. (1981). Influence of method on the apparent size distribution of bacterioplankton cells: epifluorescence microscopy compared to scanning electron microscopy. Mar. Ecol. Prog. Ser, 5: 103-106

Gerlach, S. A. (1978). Food-chain relationships in subtidal silty sand marine sediments and the role of meiofauna in stimulating bacterial productivity. Oecologia 33: 55-69

Gillespie, P. A., MacKenzie, A. L. (1981). Autotrophic and heterotrophic processes on an intertidal mud-sand flat, Delaware Inlet, Nelson, New Zealand. Bull. mar. Sci. 31 648-657

Griffiths, R. P., Hanus, F. J., Morita, R. Y. (1974). The effects of various water-sample treatments on the apparent uptake of glutamic acid by natural marine microbial populations Can. J. Microbiol. 20: 1261-1266

Haney, J. F. (1971). An in situ method for the measurement of zooplankton grazing rates. Limnol. Oceanogr. 16: 970-977

Hobbie, J. E., Crawford, C. C. (1969). Respiration corrections for bacterial uptake of dissolved organic compounds in natura] waters. Limnol. Oceanogr. 14: 528-532

Hobbie, J. E., Daley, R. J., Jasper, S. (1977). Use of Nuclepore filters for counting bacteria by fluorescence microscopy. Appl. environ. Microbiol. 33: 1225-1228

Holm Hansen, O., Lorenzen, C. J., Holmes, R. W., Strickland J. D. H. (1965). Fluorometric determination of chlorophyll. J. Cons. perm. int. Explor. Mer 30: 3-15

Kempthorne, O., Allmaras, R. R. (1965). Errors of observation. In: Black, C. A. (ed.) Methods of soil analysis, Part 1. Physical and minerological properties, including statistics of measurement and sampling. Am. Soc. Agronomy, Madison, 1965: 1-23

Klekowski, R. Z., Schiemer, F., Duncan, A. (1979). A biogenic study of a benthic nematode, Plectus palustris de Man 1880, throughout its life cycle. Oecologia 44: 119-124

Kuipers, B. R., de Wilde, P. A. W. J., Creutzberg, F. (1981) Energy flow in a tidal flat ecosystem. Mar. Ecol. Prog. Ser. 5: $215-221$

Lampert, W. (1975). A tracer study on the carbon turnover of Daphnia pulex. Verh. internat. Verein. Limnol. 19: 2913-2921

Lee, J. J., Tietjen, J. H., Mastropaolo, C., Rubin, H. (1977). Food quality and the spatial distribution of meiofauna. Helgoländer wiss. Meeresunters. 30: 272-282

McIntyre, A. D. (1969). Ecology of marine meiobenthos. Biol. Rev. 44: $245-290$

Meyer-Reil, L.-A. (1978). Uptake of glucose by bacteria in the sediment. Mar. Biol. 44: 293-298

Meyer-Reil, L.-A., Faubel, A. (1980). Uptake of organic matter by meiofauna organisms and interrelationship with bacteria. Mar. Ecol. Prog. Ser. 3: 251-256

Meyer-Reil, L.-A., Dawson, R., Liebezeit, G., Tiedge, H. (1978). Fluctuations and interactions of bacterial activity in sandy beach sediments and overlying waters. Mar. Biol. 48: $161-171$

Montagna, P. A. (1982). Sampling design and enumeration statistics for bacteria extracted from marine sediments. Appl. environ. Microbiol. 43: 1366-1372 
Montagna, P. A. (1983). Live controls for radioisotope tracer food chain experiments using meiofauna. Mar. Ecol. Prog. Ser. $12: 43-46$

Montagna, P. A. (1984). Competition for dissolved glucose between meiofauna and sediment bacteria. J. exp. mar. Biol. Ecol. 76: 177-190

Montagna, P. A., Coull, B. C., Herring, T. L., Dudley, B. W. (1983). The relationship between abundances of meiofauna and their suspected microbial food (diatoms and bacteria). Estuar. coast. Shelf Sci. 17: 381-394

Moriarty, D. J. W., Pollard, P. C. (1981). DNA synthesis as a measure of bacterial productivity in seagrass sediments. Mar. Ecol. Prog. Ser. 5: 151-156

Newell, S. Y., Fallon, R. D. (1982). Bacterial productivity in the water column and sediments of the Georgia (USA) coastal zone: estimated via direct counting and parallel measurement of Thymidine incorporation. Microb. Ecol. 8: $33-46$

Persson, G. (1982). Losses of isotopic label upon liquid preservation of zooplankton in feeding and assimilation studies. Arch. Hydrobiol. 94: 502-519

Porter, K. G. (1976). Enhancement of algal growth and productivity by grazing zooplankton. Science, N. Y. 192 $1332-1333$

Rieper, M. (1978). Bacteria as food for marine harpacticoid copepods. Mar. Biol. 45: 337-345

Rieper, M. (1982\}. Feeding preferences of marine harpacticoid copepods for various species of bacteria. Mar. Ecol. Prog. Ser. 7: 303-307

Rieper, M., Flotow, C. (1981). Feeding experiments with bacteria ciliates and harpacticoid copepods. Kieler Meeresforsch. Sonderh. 5: 370-375

Rodina, A. G. (1972). Methods in aquatic microbiology (Translated, edited and revised from Russian by R. R Colwell and M. S. Zambruski). University Park Press, Baltimore

Roman, M. R., Rublee, P. A. (1981). A method to determine in situ zooplankton grazing rates on natural particle assemblages. Mar. Biol. 65: 303-309

Rublee, P. A. (1982). Seasonal distribution of bacteria in salt marsh sediments in North Carolina. Estuar coast. Shelf Sci. 15: $67-74$

Schiemer, F. (1982a). Food dependence and energetics of freeliving nematodes. I. respiration, growth and reproduction of Caenorhabditis briggsae (Nematoda) at different levels of food supply. Oecologia 54: 108-121

Schiemer, F. (1982b). Food dependence and energetics of freeliving nematodes. II. life history parameters of Caenorhabditis briggsae (Nematoda) at different levels of food supply. Oecologia 54: 122-128

Schiemer, F., Duncan, A., Klekowski, R. C. (1980). A bioenergetic study of a benthic nematode, Plectus palustris de Man 1880, throughout its life cycle. II. Growth, fecun- dity and energy budgets at different levels of bacterial food and general ecological considerations. Decologia 44: 205-212

Schwinghammer, P. (1981). Characteristic size distributions of integral benthic communities. Can. J. Fish. Aquat. Sci 38: $1255-1263$

Sellner, B. W. (1976). Survival and metabolism of the harpacticoid copepod Thompsonula hyaenae (Thompson) fed different diatoms. Hydrobiologia 50: 233-238

Snedecor, G. W., Cochran, W. G. (1967). Statistical methods 6th ed. Iowa State University Press, Ames

Strickland, J. D. H., Parsons, T. R. (1972). A practical handbook of seawater analysis. Bull. Fish. Res. Bd Can. 122: $1-172$

Taghon, G. L. (1981). Beyond selection: optimal ingestion rate as a function of food value. Am. Nat. Bd. 118: 202-214

Tenore, K. R. Tietjen, J. H., Lee, J. J. (1977). Effects of meiofauna on incorporation of aged eelgrass by polychaete, Nepthys incisa. J. Fish. Res. Bd Can. 34: 563-567

Tietjen, J. H. (1980). Microbial-meiofaunal interrelationships: a review. Microbiology 1980: 335-338

Tietjen, J. H., Lee, J. J. (1973). Life history and feeding habits of the marine nematode, Chromadora macrolaimoides Steiner. Oecologia 12: 303-314

Ustach, J. F. (1982). Algae, bacteria and detritus as food for the harpacticoid copepod, Heteropsyllus pseudonunni Coull and Palmer. J. exp. mar. Biol. Ecol. 64: 203-214

Vanden Berghe, W., Bergmans, M. (1981). Differential food preferences in three co-occurring species of Tisbe (Copepoda, Harpacticoida). Mar. Ecol. Prog. Ser. 4: 213-219

Warwick, R. M., Joint, I. R., Radford, P. J. (1979). Secondary production of the benthos in an estuarine environment. In Jefferies, R. L., Davy, A. J. (ed.) Ecological processes in coastal environments. Blackwell Scientific Publications Oxford, p. 429-450

Williams, R., Robins, D. B. (1982). Effects of preservation on wet weight, dry weight, nitrogen and carbon contents of Calanus helgolandicus (Crustacea: Copepoda). Mar. Biol 71: 271-281

Wilson, C. A., Stevenson, L. H. (1980). The dynamics of the bacterial population associated with a salt marsh. J. exp. mar. Biol. Ecol. 48: 123-138

Wright, R. T., Hobbie, J. J. (1966). Use of glucose and acetate by bacteria and algae in aquatic ecosystems. Ecology 47 : $447-464$

Zeeman, S. I. (1983). Phytoplankton photosynthesis and its relation to light intensity in a turbid estuary and the nearshore coastal ocean. $\mathrm{Ph}$. D. dissertation, The University of South Carolina, Columbia

Zobell, C. E., Feltham, C. B. (1942). The bacterial flora of a marine mudflat as an ecological factor. Ecology 23: 69-78 